\title{
Associations between Dependency Behavior and Management Ability in A Cross-Sectional Study of Mother who Care for Children with Avoidant Restrictive Food Intake Disorder
}

\author{
Yoyok Bekti Prasetyo ${ }^{1}$, Alia Syamsudin ${ }^{1}$, Faqih Ruhyanuddin² ${ }^{2}$ Edi Purwanto ${ }^{2}$, Nursalam \\ Nursalam ${ }^{3}$, Rachmat Hargono ${ }^{4}$, Ahsan Ahsan ${ }^{5}$ \\ ${ }^{1,2}$ Faculty of Health Sciences, University of Muhammadiyah Malang, Malang, Indonesia \\ ${ }^{3}$ Faculty of Nursing, Airlangga University, Surabaya, Indonesia \\ ${ }^{4}$ Faculty of Public Health, Airlangga University, Surabaya, Indonesia \\ ${ }^{5}$ Medical Faculty, Brawijaya University of Malang, Malang, Indonesia \\ Correspondingemail:yoyokbekti2@gmail.com/yoyok@umm.ac.id
}

Submitted: 16-01-2020 Accepted: 19-02-2020 Published: 01-04-2020

\begin{abstract}
ARFID phenomena commonly found on children are strongly dependent on parental behaviors. A dependency behavior shown by parents constitutes a specific behavior that helps the parents fulfill children's needs. This kind of behavior will define a parental management ability in dealing with eating disorder phenomena on their children. This research, therefore, was set to analyze parental dependency behavior on parental management ability in dealing with eating disorder phenomena. A cross-sectional design was occupied to accommodate the research. A total of 245 families were selected to be the respondents, especially those who were taking care of children with ARFID. Data were collected using self-administered questionnaire. For descriptive data analysis, Manne-Whitney U test, one-way analysis of variance, Kruskal-Wallis, correlation product moment, and multiple linear regression were employed. Parental dependency behavior was closely related to parental management ability in dealing with eating disorder phenomena, especially in taking care of children with ARFID $(r=0.354 ; p=0.000<0.05)$. This dependency behavior encompassed parents calming children down (with $p=0.000<0.05$ ), giving hug to children $(p=0.000<0.05)$, listening to children $(p=0.001<0.05)$, solving children's problems $(p=0.000<0.05)$ and fulfilling needs of food and drink $(\mathrm{p}=0.000<0.05)$. On top of that, parental management ability in dealing with eating disorder occurrence was perceived referring to the result of multiple linear regression analysis, which was said to be mainly influenced by a predictor of parental dependency behavior in solving children's problems (with $\beta=0.211 ; p=0.001$ ) and fulfilling children's needs of food and drink (with $\beta=0.134 ; p=0.047$ ).Parental management ability in dealing with eating disorder was necessarily influenced by parental dependency behavior in solving children's problems and fulfilling children's needs of food and drink. Therefore, we suggest that nursing intervention be provided in respect of this case upon the population of families taking care of children with ARFID.
\end{abstract}

Keywords: ARFID, parental dependency behavior, parental management ability in dealing with eating disorder occurrence. 
Yoyok Bekti Prasetyo: Assosiations between Dependency Behavior and Management Ability

\section{Introduction}

Parental dependency behavior refers to a specific behavior to provide children with assistance in response to parenting needs, particularly in physical and attention forms. On one hand, dependency is defined as " ... it's clearly not in control of itself" (Groarke, 2016). In short, parental dependency behavior is a particular behavior that aims at giving assistance to children in response to parenting obligatory needs in forms of attention or confession and physical assistance (Fawcett, 2017). that children are highly dependent on their parents in terms of fulfilment of food need (Hansson et al., 2016; Herschell et al., 2016).

Problems rising in parental dependency behavior can be instigated by knowledge on children's nutritional status and physical assistance on children. In fact, majority of parents are found unaware of their children's nutritional status with a number of $97 \%$ (Munthofiah, 2010). In addition, a total of $57.4 \%$ of parents are still categorized aware, but with not really high level of awareness (Bumi, 2015). On one hand, as many as $31.5 \%$ of parents do not directly provide their children with physical assistance, mainly in serving food and drink to the children, due to occupational and other contributing factors (Hidayati, 2011). As a consequence of low dependency behavior, children are found to have poor dietary habit. Moreover, $44.4 \%$ of children commit unhealthy lifestyle, buying unhealthy food (Sitoresmi, 2014). On top of that, lack of attention given by parents also results in children's nutritional disorder due to minimum fulfilment of food need by the parents (Spruijt et al., 2018).

Parental dependency behavior can elevate a behavioral response of giving attention. Children's age aggregate is equipped with high dependency on parents as regards fulfilment of food need (Hansson et al. 2016; Herschell et al. 2016). Children suffering from eating disorder are significantly influenced by a factor of dependency (Ben-Porath et al., 2014) so that parents are required to create a pleasant eating behavior and promote children's independency in fulfilling their own needs (Cullinane \& Novak, 2013)

health management refers to actions of identifying, controlling, showing up, and integrating several conducts as an attempt for defensive action for the sake of status of health and prosperity (Johnson et al., 2000; McCloskey et al., 1996). Further, there are also some indicators for eating disorder management, such as: cooperation with health team, cooperation with family members, involvement and development on positive relationship, monitoring on vital signs, monitoring intake of fluid output, defining desired expectation, making use of behavioral modification, discussion with health team, and taking over responsibility. Avoidant Restrictive Food Intake Disorder (ARFID)

Avoidant Restrictive Food Intake Disorder constitutes a new term to draw upon eating disorder on infants and toddlers with some characteristics of: refusing to eat, having poor eating schedule, showing up poor eating skills (inappropriate with children's normal development stage) (Davies et al., 2006), and less tempted to eat. In addition, the avoidance is due to food sensor covering look, smell and taste, fear of eating (dysphagia), and fear of swallowing food (Fisher et al., 2014; Kostro, Lerman, \& Attia, 2014; Nicely et al., 2014) Children with ARFID are in need of assistance from parents to give protection, direction, and family support (Cismaru \& Pioufle, 2016) What is more, this research was mainly intended to analyze the influence of parental dependency behavior on parental management ability in dealing with eating disorder on children with ARFID.

\section{Method}

\section{Research Design}

This current research occupied descriptive cross-sectional survey design.

\section{Setting and sample characteristics}

The study was conduct in Malang District, Indonesia, between August 2018 and February 2019. The sample size was determined based on the rule of tumb in structural equation modelling, which is to multiply the total number of parameters by 5 or 10 (Azman, 2017). Normally, there are 10 paramaters included; thus, the total sample would be 10 
Yoyok Bekti Prasetyo: Assosiations between Dependency Behavior and Management Ability

$\mathrm{x} 10$, which would equal 100 participants (minimum number). There were 245 potential participants. Multistage sampling was employed to gradually determine the final size of the sample (Taherdoost, 2018).

In addition, there were inclusive criteria of the respondents, such as that: 1) they took care of 5-year-old children; 2) the children suffered from ARFID which were shown by the following symptoms, such as food avoidance based on food sensor including look, smell and taste; 3 ) the children did not suffer from chronical illnesses; and 4) the children were not congenitally disordered, especially on dietary tract.

\section{Questionnaire}

Data collection was executed through questionnaire. The questionnaire of dependency behavior was developed from Johnson Behavioral System Models consisted of 6 (six) items in total with some indicators of:1) calming children down when crying or sad, 2) giving hug when in fear, 3) keeping eye contact, 4) listening to children's problems, 5) helping solve the problems, and 6) providing children with food and drink. Each of the items was equipped with 5-point Likert scale with the descriptors of: $1=$ never, $2=$ seldom, $3=$ sometimes, $4=$ frequently, $5=$ always). Moreover, the validity values of the six domains signified: $0.40 ; 0.58 ; 0.53 ; 0.76$; 0.73 ; and 0.40 , with Cronbach's Alpha value of 0.62 . The questionnaire of management in eating disorder developed from manual book nursing intervention criteria occurrence comprised 9 (nine) items with indicators of : cooperation with health team, cooperation with family members, involvement and development on positive relationship, monitoring on vital signs, monitoring intake of fluid output, defining desired expectation, making use of behavioral modification, discussion with health team, and taking over responsibility, with the use of 5-point Likert scale with the descriptors of: $1=$ never,
$2=$ seldom, $3=$ sometimes, $4=$ frequently, $5=$ always). the validity values of the nine domains consecutively signified: $0.74 ; 0.72$; $0.71 ; 0.72 ; 0.73 ; 0.81 ; 0.84 ; 0.77 ; 0.77$, with Cronbach's Alpha value of 0.88 .

\section{Data Collection}

Data of the research were collected in between August 2018 and February 2019, The questionnaire, further, was administered to integrated public health service posts and/ or residences on the targeted area. In fact, there were a total of 245 participants involved.

\section{Data Analysis}

The whole data were analyzed using IBM SPSS Statistics 23.0 software (IBM Corp., Armonk, NY, USA) with $\mathrm{p}<0.05$ as the level of significance. Demographic data of mothers and children were presented in a form of frequency distributions (percentages). The data of dependency behavior and management ability in dealing with eating disorder phenomena were presented as mean values (or standard deviation). Moreover, Pearson Correlation Coefficient was occupied to analyze the correlation between parental dependency behavior and management ability in dealing with eating disorder occurrence. In addition, multiple linear regression was used to examine the influence of parental dependency behavior on management ability in dealing with eating disorder occurrence, especially for those mothers taking care of children with ARFID. Initially, this research had been granted an ethical approval from ethical committee of research of Faculty of Public Health, Airlangga University with reference number of 333-KEPK. All the participants had also written informed consent alongside their signatures. Thus, privacy and confidentiality were totally assured.

Table 1 Demographical Characteristics of Mothers and Children

\begin{tabular}{lccccc}
\hline \multirow{2}{*}{ Characteristics } & \multicolumn{5}{c}{ Parental Dependency Behavior } \\
\cline { 2 - 6 } & Good & Fair & Poor & Total & P Value \\
\cline { 2 - 6 } & $\mathbf{n ~ ( \% )}$ & $\mathbf{n ~ ( \% )}$ & $\mathbf{n ~ ( \% )}$ & $\mathbf{n ~ ( \% )}$ \\
\hline Age & & & & 0.207 \\
$17-25$ & $14(23.0 \%)$ & $37(6.7 \%)$ & $10(16.4 \%)$ & $61(100 \%)$ & 0.007 \\
\hline
\end{tabular}

Volume 8 Issue 1 April 2020 
Yoyok Bekti Prasetyo: Assosiations between Dependency Behavior and Management Ability

\begin{tabular}{|c|c|c|c|c|c|}
\hline \multirow[t]{3}{*}{ Characteristics } & \multicolumn{4}{|c|}{ Parental Dependency Behavior } & \multirow[b]{2}{*}{ P Value } \\
\hline & Good & Fair & Poor & Total & \\
\hline & n (\%) & n (\%) & n (\%) & n (\%) & \\
\hline $26-35$ & $31(22.3 \%)$ & $95(68.3 \%)$ & $13(9.4 \%)$ & $139(100 \%)$ & \\
\hline $36-45$ & $5(11.1 \%)$ & $36(80.0 \%)$ & $4(8.9 \%)$ & $45(100 \%)$ & \\
\hline \multicolumn{6}{|c|}{ Educational Background } \\
\hline Elementary School & $9(18.0 \%)$ & $36(72.0 \%)$ & $5(10.0 \%)$ & $50(100 \%)$ & 0.078 \\
\hline Junior High School & $12(16.0 \%)$ & $52(69.3 \%)$ & $11(14.7 \%)$ & $75(100 \%)$ & \\
\hline Senior High School & $26(29.2 \%)$ & $53(59.6 \%)$ & $10(12.2 \%)$ & $89(100 \%)$ & \\
\hline Higher Education & $3(9.7 \%)$ & $27(87.1 \%)$ & $1(3.2 \%)$ & $31(100 \%)$ & \\
\hline \multicolumn{6}{|l|}{ Employment } \\
\hline Unemployed & $42(22.1 \%)$ & $130(68.4 \%)$ & $18(9.5 \%)$ & $190(100 \%)$ & 0.219 \\
\hline Employed & $8(14.5 \%)$ & $38(69.1 \%)$ & $9(16.4 \%)$ & $55(100 \%)$ & \\
\hline \multicolumn{6}{|l|}{ Number of Children } \\
\hline 1 & $20(19.2 \%)$ & $70(67.3 \%)$ & $14(13.5 \%)$ & $104(100 \%)$ & 0.868 \\
\hline 2 & $21(21.6 \%)$ & $67(69.1 \%)$ & $9(9.3 \%)$ & $97(100 \%)$ & \\
\hline 3 & $9(25.0 \%)$ & $24(66.7 \%)$ & $3(8.3 \%)$ & $36(100 \%)$ & \\
\hline 4 & - & $6(85.7 \%)$ & $1(14.3 \%)$ & $7(100 \%)$ & \\
\hline 5 & - & $1(100.0 \%)$ & - & $1(100 \%)$ & \\
\hline \multicolumn{6}{|l|}{ Monthly Income } \\
\hline$<1$ Juta & $10(17.9 \%)$ & $36(64.3 \%)$ & $10(17.9 \%)$ & $56(100 \%)$ & 0.336 \\
\hline Between 1-2 Juta & $29(23.0 \%)$ & $87(69.0 \%)$ & $10(7.9 \%)$ & $126(100 \%)$ & \\
\hline$>2$ Juta & $11(17.5 \%)$ & $45(71.4 \%)$ & $7(11.1 \%)$ & $63(100 \%)$ & \\
\hline \multicolumn{6}{|l|}{ Children's Age } \\
\hline 0-3 years old & $40(22.6 \%)$ & $120(67.8 \%)$ & $17(9.6 \%)$ & $177(100 \%)$ & 0.257 \\
\hline$>3-5$ years old & $10(14.7 \%)$ & $48(70,6 \%)$ & $10(14.7 \%)$ & $68(100 \%)$ & \\
\hline \multicolumn{6}{|l|}{ Children's Gender } \\
\hline Male & $22(20.0 \%)$ & $76(69.1 \%)$ & $12(10.9 \%)$ & $110(100 \%)$ & 0.987 \\
\hline Female & $28(20.7 \%)$ & $92(68.1 \%)$ & $15(11.1 \%)$ & $135(100 \%)$ & \\
\hline \multicolumn{6}{|c|}{ Children's Body Weight } \\
\hline Very Underweight & $1(14.3 \%)$ & $6(85.7 \%)$ & - & $7(100 \%)$ & 0.485 \\
\hline Underweight & $10(25.6 \%)$ & $24(61.5 \%)$ & $5(12.8 \%)$ & $39(100 \%)$ & \\
\hline Normal/Ideal & $39(19.8 \%)$ & $137(69.5 \%)$ & $21(10.7 \%)$ & $197(100 \%)$ & \\
\hline Overweight & - & $1(50.0 \%)$ & $1(50.0 \%)$ & $2(100 \%)$ & \\
\hline \multicolumn{6}{|c|}{ Children's Body Height } \\
\hline Very Short & $13(26.0 \%)$ & $32(64.0 \%)$ & $5(10.0 \%)$ & $50(100 \%)$ & 0.771 \\
\hline Short & $7(18.4 \%)$ & $26(68.4 \%)$ & $5(13.2 \%)$ & $38(100 \%)$ & \\
\hline Normal & $27(18.1 \%)$ & $106(71.1 \%)$ & $16(10.7 \%)$ & $149(100)$ & \\
\hline Tall & $3(37.5 \%)$ & $4(50.0 \%)$ & $1(12.5 \%)$ & $8(100 \%)$ & \\
\hline
\end{tabular}


Yoyok Bekti Prasetyo: Assosiations between Dependency Behavior and Management Ability

Table 2 Parental Management ability in dealing with eating Disorder Occurrence

\begin{tabular}{|c|c|c|c|c|c|}
\hline \multirow[t]{3}{*}{ Characteristics } & \multicolumn{4}{|c|}{ Parental Dependency Behavior } & \multirow[b]{2}{*}{ P Value } \\
\hline & Good & Fair & Poor & Total & \\
\hline & n (\%) & n (\%) & n (\%) & n (\%) & \\
\hline \multicolumn{6}{|l|}{ Mothers' Age } \\
\hline $17-25$ & $15(24.6)$ & $40(65.6)$ & $6(9.8)$ & $61(100 \%)$ & 0.048 \\
\hline $26-35$ & $18(12.9)$ & $102(73.4)$ & $19(13.7)$ & $139(100 \%)$ & \\
\hline $36-45$ & $2(4.4)$ & $35(77.8)$ & $8(17.8)$ & $45(100 \%)$ & \\
\hline \multicolumn{6}{|c|}{ Educational Background } \\
\hline Elementary School & $5(10.0)$ & $35(70.0)$ & $10(20.0)$ & $50(100 \%)$ & 0.049 \\
\hline Junior High School & $10(13.3)$ & $49(65.3)$ & $16(21.3)$ & $75(100 \%)$ & \\
\hline Senior High School & $15(16.9)$ & $68(76.4)$ & $6(6.7)$ & $89(100 \%)$ & \\
\hline Higher Education & $5(16.1)$ & $25(80.6)$ & $1(3.2)$ & $31(100 \%)$ & \\
\hline \multicolumn{6}{|l|}{ Employment } \\
\hline Unemployed & $28(14.7)$ & $138(72.6)$ & $24(12.6)$ & $190(100 \%)$ & 0.749 \\
\hline Employed & $7(12.7)$ & $39(70.9)$ & $9(16.4)$ & $55(100 \%)$ & \\
\hline \multicolumn{6}{|l|}{ Number of Children } \\
\hline 1 & $23(22.1)$ & $73(70.2)$ & $8(7.7)$ & $104(100 \%)$ & 0.018 \\
\hline 2 & $10(10.3)$ & $74(76.3)$ & $13(13.4)$ & $97(100 \%)$ & \\
\hline 3 & $2(5.6)$ & $24(66.7)$ & $10(27.8)$ & $36(100 \%)$ & \\
\hline 4 & - & $5(71.4)$ & $2(28.6)$ & $7(100 \%)$ & \\
\hline 5 & - & $1(100)$ & - & $1(100 \%)$ & \\
\hline \multicolumn{6}{|l|}{ Monthly Income } \\
\hline$<1$ Juta & $7(12.5)$ & $37(66.1)$ & $12(21.4)$ & $56(100 \%)$ & 0.248 \\
\hline Between 1-2 Juta & $16(12.7)$ & $95(75.4)$ & $15(11.9)$ & $126(100 \%)$ & \\
\hline$>2$ Juta & $12(19.0)$ & $45(71.4)$ & $6(9.5)$ & $63(100 \%)$ & \\
\hline \multicolumn{6}{|l|}{ Children's Age } \\
\hline $0-3$ years old & $25(14.1)$ & $126(71.2)$ & $26(14.7)$ & $177(100 \%)$ & 0.665 \\
\hline$>3-5$ years old & $10(14.7)$ & $51(75.0)$ & $7(10.3)$ & $68(100 \%)$ & \\
\hline \multicolumn{6}{|l|}{ Children's Gender } \\
\hline Male & $17(15.5)$ & $79(71.8)$ & $14(12.7)$ & $110(100 \%)$ & 0.870 \\
\hline Female & $18(13.3)$ & $98(72.6)$ & $19(14.1)$ & $135(100 \%)$ & \\
\hline \multicolumn{6}{|c|}{ Children's Body Weight } \\
\hline Very Underweight & $2(28.6)$ & $4(57.1)$ & $1(14.3)$ & $7(100 \%)$ & 0.826 \\
\hline Underweight & $7(17.9)$ & $26(66.7)$ & $6(15.4)$ & $39(100 \%)$ & \\
\hline Normal/Ideal & $26(13.2)$ & $145(73.6)$ & $26(13.2)$ & $197(100 \%)$ & \\
\hline Overweight & - & $2(100)$ & - & $2(100 \%)$ & \\
\hline \multicolumn{6}{|c|}{ Children's Body Height } \\
\hline Very Short & $7(14.0)$ & $32(64.0)$ & $11(22.0)$ & $50(100 \%)$ & 0.096 \\
\hline Short & $6(15.8)$ & $29(76.3)$ & $3(7.9)$ & $38(100 \%)$ & \\
\hline Normal & $20(13.4)$ & $113(75.8)$ & $16(10.7)$ & 149(100) & \\
\hline Tall & $35(14.3)$ & $3(37.5)$ & $3(37.5)$ & $8(100 \%)$ & \\
\hline
\end{tabular}


Yoyok Bekti Prasetyo: Assosiations between Dependency Behavior and Management Ability

Table 3 The Correlation between Parental Dependency Behavior and Management Ability in Dealing with eating Disorder Occurrence $(\mathbf{r} / \mathbf{p})$

\begin{tabular}{lc}
\hline \multicolumn{1}{c}{ Variables } & Management Ability \\
\hline Parental Dependency Behavior & $0.354 / 0.000$ \\
\hline Calming children down & $0.243 / 0.000$ \\
Giving hug to children & $0.288 / 0.000$ \\
Keeping eye contact & $0.064 / 0.316$ \\
Listening to children & $0.205 / 0.001$ \\
Solving children's problems & $0.301 / 0.000$ \\
Fulfilling children's needs of food and drink & $0.281 / 0.000$ \\
\hline
\end{tabular}

Table 4 Multiple Linear Regression of The Influence of Parental Dependency Factor Corresponding to Management Ability in Dealing with Eating Disorder Occurrence

\begin{tabular}{lccccc}
\hline \multicolumn{1}{c}{ Variables } & $\mathbf{B}$ & $\mathbf{S E}$ & $\boldsymbol{\beta}$ & $\mathbf{t}$ & $\mathbf{p}$ \\
\hline Constants & 15.371 & 4.716 & & 3.260 & 0.001 \\
Calming down children & 0.531 & 0.795 & 0.046 & 0.668 & 0.505 \\
Giving hug to children & 1.098 & 0.679 & 0.112 & 1.617 & 0.107 \\
Keeping eye contact & -0.038 & 0.353 & -0.007 & -0.107 & 0.915 \\
Listening to children & 0.697 & 0.403 & 0.112 & 1.730 & 0.085 \\
Solving children's problems & 1.557 & 0.464 & 0.211 & 3.355 & 0.001 \\
Fulfilling children's needs of & 1.710 & 0.856 & 0.134 & 1.999 & 0.047 \\
food and drink & & & & & \\
\hline
\end{tabular}

Dependency Behavior as a Representative of the Characteristics of Mothers and Children

With reference to Table 1, it is shown that dependency behavior was not necessarily influenced by such factors as age, educational background, employment, number of children, and income families had made in a month as each of the factors was equipped with $p$ value of bigger than 0.05. Parental dependency behavior could be drawn from the majority of age groups, specifically in the category of $17-25$ years old (with a total of $23.0 \%$ ). According to educational background, good parental dependency behavior was shown by those graduating from senior high school with a total of $29.2 \%$. Meanwhile, referring to data of occupational domain, it is demonstrated that good parental dependency behavior was performed by unemployed parents with a total of $22.1 \%$. In respect of number of children, good parental dependency behavior was made by those taking care of 3 (three) children with a total of $25.0 \%$. In addition, those who made monthly income of $1-2$ million were also found to perform good dependency behavior with a total of $23.0 \%$. Parental dependency behavior, furthermore, was not also influenced by such other factors as children's age, gender, body weight, and body height since each of the factors had the $p$ value of bigger than 0.05 . On top of that, good practice of parental dependency behavior was demonstrated alongside the following criteria found in children, such as aging $1-3$ years old $(22.6 \%)$, female $(20.7 \%)$, having ideal body weight $(25.6 \%)$, and tall $(37.5 \%)$.

\section{Management ability in Dealing with Eating Disorder Occurrence}

With reference to Table 2, it is shown that parent's management ability in dealing with eating disorder occurrence was defined by some factors, such as mother's age (with $p$ value of 0.025 ), educational background (with $p$ value of 0.049 ) and number of children (with $p$ value of 0.018). In addition, parental management ability in dealing with eating disorder occurrence was not necessarily determined by factors of employment and income since the $p$ value was shown 
bigger than 0.05. Further, good parental management ability was demonstrated based on the following criteria, such as: mothers aging $17-25$ years old $(24.6 \%)$, graduating from senior high school $(16.9 \%)$, unemployed $(14.7 \%)$, taking care of only a child $(22.1 \%)$, and making income more than 2 million $(19.0 \%)$.

Moreover, parental management ability in dealing with eating disorder occurrence had nothing to do with some factors, in the sense of children conditions, such as age, gender, body weight, and body height since each of the factors was equipped with the $p$ value of bigger than 0.05. In fact, good parental management ability in dealing with eating disorder occurrence was performed to those aging $>3-5$ years old $(14.7 \%)$, male $(15.5 \%)$, very underweight $(28.6 \%)$, and tall $(15.8 \%)$.

\section{The Correlation between Parental} Dependency Behavior and Management Ability in dealing with eating Disorder Occurrence

Table 3 demonstrates the correlation between parental dependency behavior and management ability in dealing with eating disorder phenomenon endured by children with ARFID. The correlation was fair, with $r=0.354$. There were some parameters to define the correlation between the two variables, such as calming children down (with $\mathrm{p}=0.000<0.05$ ), giving hug to children (with $\mathrm{p}=0.000<0.05$ ), listening to children (with $\mathrm{p}=0.001<0.05$ ), solving children's problems (with $\mathrm{p}=0.000<0.05$ ) and fulfilling children's needs of food and drink (with $\mathrm{p}=0.000<0.05$ ).

\section{Parental Dependency Behavior on Management Ability in Dealing with Eating Disorder Occurrence}

Tabel 4 the result of multiple linier regression, indicating that two domains of parental dependency behavior, solving children's problems and fulfilling children's needs of food and drink, could influence parental management ability in dealing with eating disorder occurrence. In addition, parental dependency behavior in solving children's problem was assumed positively influencing management ability in dealing with eating disorder occurrence (with $\beta=$
$0.211, \mathrm{p}=0.001<0.05)$. Furthermore, parental dependency behavior in fulfilling children's needs of food and drink was also positively influencing the management ability (with $\beta=$ $0.134, \mathrm{p}=0.047<0.05$ ).

\section{Discussion}

\section{Parental Dependency Behavior Based on the Characteristics of Mothers and Children}

Parental dependency behavior had not correlation with mother's age. This was because the majority of mothers aged in the ranks of 17-25 years old, which was found equipped with good dependency behavior. Mothers aging 17-25 years old would be having better understanding on children's development so that they could reach optimum development according to their level of age (Nihen Grah Prihantanti 2017). In addition, parental dependency behavior was not influenced by educational background. High educational background could not totally ensure that mothers would be fully understanding determining factors that might influence children's nutritional status. A research carried out by Pratiwi, Masrul, and Yerizel (2016) explained that mothers who took high education would be easier in receiving information regarding how to give good attention to children. Nonetheless, alongside the massive advancement of science in any disciplines, any mothers who had attended senior high school and was found perseverant would be able to gain access to information about children's needs of nutrition (Rarastiti 2013; Solehati et al. 2017).

Henceforth, parental dependency behavior was not influenced by employment status. This was mainly because unemployed mothers would be having much more time to spend with their children so as to make them easier to control or notice their children's dietary habit very well (Bumi, 2015). In addition, the dependency behavior was not influenced by number of children. It was due to the fact that those taking care of some children ( $>1$ child) would be more enjoyable in performing their main role as a mother, primarily in fulfilling children's needs, since they had acquired previous parenting 
experiences with previous children they had been raising (Myrskylä \& Fenelon, 2012). Also, the dependency behavior did not also correlate with income. Different amount of income people had made would be making them have different lifestyle. those parents making income of 1-2 million would be easier in fulfilling children's needs. Thus, their needs of food and drink will be of great assurance (Rohma, 2017).

\section{Management ability in dealing with eating Disorder Occurrence Based on the Characteristics of Mothers and Children}

Good management ability in dealing with eating disorder occurrence refers to a specific attitude shown by parents to their children for the sake of warmth, sensitivity, and awareness of limitation in addition to enforcement to children (Taraban \& Shaw, 2018). The management ability was influenced by mothers' age (with $p$ value of 0.048 ). In addition, age was also assumed one of factors influencing mothers' attention. Parenting was categorized good only if mothers age belonged to criteria of 17-35 years old (Hidayah, 2017),. The research indicated that a rank of ages strongly influenced parenting style. When mothers were too mature and young, therefore, they could not do their role optimally since, in parenting, it was in need of both physical and psychosocial strengths. In addition, those who were ideally more mature and stable, in terms of psychological condition, would be able to performed a quality parenting style for their children (Burlaka, Graham-Bermann, \& Delva, 2017). children who were born from mothers aging younger than 17 years old or older than 25 years old would be having more negative outcome with reference to health, body weight, and obesity probability than those born from mothers aging 17-25 years old (Myrskylä \& Fenelon, 2012).

Management ability in dealing with eating disorder occurrence was influenced by educational background (with $p$ value of 0.049 ). The majority of the respondents who were identified graduating from senior high school was categorized good in terms of management on eating disorder occurrence. The educational background possessed by parents, further, would influence parental behavior in doing parenting upon their children. Those mothers who were senior high school graduates would not only make very simple understanding, but also do good parenting and provide children with anything they were in need of. This was because of the presence of awareness that to support children optimally, they did not only need one thing to complete, but also things considered vital (Bao et al. 2016; Uyun, Fitri, dan Rakhmawati 2013).

Management ability in dealing with eating disorder occurrence was not influenced by status of employment. Most of the respondents were unemployed and had performed good management in dealing with eating disorder occurrence. Unemployed mothers would be having more time to keep their children company, managing and raising their children with the ultimate aim of giving serious attention to children's nutritional supply (Labada, 2016). According to the research, it was shown that there were some other factors found to influence parenting style in managing children's eating disorder occurrence.

Factor of number of children raised in a family was also proved influencing management ability in dealing with eating disorder occurrence with a category of good (with $p$ value of 0.018). A good parenting applied in managing eating disorder occurrence on children was majorly performed by those respondents taking care of a child (Adawiah, 2017). In addition, her research claimed that number of children possessed by a family would give influence upon parenting style. The more the number of children in a family, the less maximum the parenting would work since the parents' time would be divorced between one to others.

Furthermore, management ability in dealing with eating disorder was not influenced by factor of income. With reference to a research carried out by (Widyastuti, 2017), it was stated that the higher the parents' income was, the better the parenting style would be. Allegedly, this was due to the fact that high income made by families would make them much easier to fulfill their children's needs of food and drink (Kartiko 2013). 


\section{The Influence of Parental Dependency Behavior on Management ability in dealing with eating Disorder Occurrence}

Parental dependency behavior

constituted the ultimate factor to define management ability in dealing with eating disorder occurrence. This was because the dependency behavior shown up through attitudes and behaviors in educating, guiding, communicating with, and doing many things with children was aimed at fulfilling children's basic needs as well as influencing children's characteristics (Nurhayati, 2017). To actualize the dependency behaviors, some actions could represent, such as giving attention to children, getting close to children, and giving physical assistance in a form of support to children. Henceforth, the primary aspect of dependency referred to attention. Parental attention was considered pivotal to be highlighted by parents towards their children since it encompassed exemplary model and direction which would be positively influencing children's growth and development (Fausi, 2017). Parental attention and awareness of children would make the children feel loved and safe. One of various examples could be by inviting other children to have a talk, listen to what was children are talking about, and giving praise to children based on their achievement (Rezky, 2010). On top of that, parental attention to children was strongly influencing the occurrence of children's eating disorder for the attention could be given by both fathers and mothers in event of fulfilling children's needs of food and drink (Fausi, 2017).

Parental dependency behavior, moreover, was in a form of either physical assistance or support. Both the physical assistance and support was alleged very influencing upon children's eating disorder since they constituted social support that could be provided by parents or families which were deemed positive to children in response to their needs. In addition, parental support also manifested a form of receival from parents to children so as to raise children's perception that they were loved, recked, and respected (Zahra, 2018). Parental support would raise warmth in the relationship of parents and children and was so responsive that parents could interact with children regularly and respond to children's needs of food (Lopez et al., 2018).

Parental dependency behavior in fulfilling children's needs of food and drink would make children feel so happy and contented when all they needed were fully fulfilled. Nutritious food and intensive stimulation from parents were obviously necessary for children's growth and development (Haerunisa, Taftazani, dan Apsari 2014; Naim, Juniarti, dan Yamin 2017; Rahayuwati et al. 2019). Taking over full responsibility of children's physical activities and food, according, had made mothers play important roles for basic need fulfilment which was categorized into 3 (three), namely affection, attention, and safety for the sake of their growth and development based on their age level (Rarastiti, 2013). Parenting needs, especially in fulfilling children's needs, covered needs for raising and caring of children, such as fulfilment of food and drink, in order to preserve children's health. By doing so, children could grow up physically, mentally, socially, and spiritually healthy. Besides, the parenting need was also defined as fulfilment of children's needs of education so that they would transform to be more independent and prepared for their future.

\section{Conclusion}

Parental dependency behavior constitutes an important factor in defining management ability in dealing with eating disorder occurrence. Parental skill in solving children's problems and parental ability to fulfil children's needs of food and drink shown by a good pattern of feeding would be impactful to manage children with ARFID. This can be a basis for further consideration, especially for the community of nurses, to design a series of plans as a form of nursing intervention in an attempt to prevent the occurrence of nutritional disorder on children with ARFID.

\section{Acknowledgement}

An enormous gratitude be always upon Bapak Faqih Ruhyanudin as the Dean of Faculty of Health Sciences, University of Muhammadiyah Malang who has granted 
Yoyok Bekti Prasetyo: Assosiations between Dependency Behavior and Management Ability

support for the accomplishment of this current research.. At last, a dutiful gratitude be upon all the participants who had been willing to involve in the research.

\section{References}

Adawiah, R. (2017). Pola asuh orang tua dan implikasinya terhadap pendidikan anak. (Ways of Parenting and Its Implications for Children's Education). Jurnal Pendidikan Kewarganegaraan, 7(1): 33-48.

Azman, A. H. N. (2017). Structural Equation Modeling (SEM): Confirmatory Factor Analysis (CFA).72(1): 1-11. http://dx.doi. org/10.13140/RG.2.2.25615.38565

Bao, P., Jing, J., Jin, Y., Hu, X., Liu, B., \& Hu, M. (2016) Trajectories and the influencing factors of behavior problems in preschool children: a longitudinal study in Guangzhou, China. BMC Psychiatry 16(178). https://doi. org/10.1186/s12888-016-0864-Z

Ben-Porath, D.D., Federici, A., Wisniewski, L., Warren, M. (2014). Dialectical behavior therapy: Does it bring about improvements in affect regulation in individuals with eating disorders?. J Contemp Psychother 44, 245251. https://doi.org/10.1007/s10879-0149271-2

Bumi, Cindar. 2015. Pengaruh Ibu yang Bekerja Terhadap Status Gizi Diajukan dalam rangka penyelesaian studi Strata 1 Untuk mencapai gelar Sarjana Kesehatan Masyarakat Universitas Negeri Semarang. [Bachelor's thesis, Semarang State University]. Universitas Negeri Semarang. Retrieved July 20, 2019, from http://lib. unnes.ac.id/726/1/1280.pdf

Burlaka, V., Graham-Bermann, S. A., \& Delva, J. (2017). Family factors and parenting in Ukraine. Child abuse \& neglect, 72, 154-162. https://doi.org/10.1016/j. chiabu.2017.08.007

Cismaru, M., \& Pioufle, A.L.(2016). Helping families affected by depression: Incorporating prosocial and caregiving literature. International Bussiness Research,
9(12),23-31. https://doi.org/10.5539/ibr. v9n12p23

Cullinane, D., \& Novak, P. (2013). Parent's/ caregiver's relationship and the impact on nutrition. Childhood Obesity and Nutrition, 5(5): 2013-2016. https://doi. org/10.1177\%2F 1941406413496569

Davies, W. H., Satter, E., Berlin, K. S., Sato, A. F., Silverman, A. H., Fischer, E. A., Arvedson, J. C., \& Rudolph, C. D. (2006). Reconceptualizing feeding and feeding disorders in interpersonal context: the case for a relational disorder. Journal of Family Psychology , 20(3), 409-417. https://doi. org/10.1037/0893-3200.20.3.409

Pratiwi, T.D., Masrul, \& Yerizel, E. (2016). Hubungan Pola Asuh Ibu dengan Status Gizi Balita di Wilayah Kerja Puskesmas Belimbing Kota Padang. (The Relationship of Mother Parenting Patterns with Nutritional Status of Toddlers in the Working Area of Belimbing Health Center Padang City). Jurnal Kesehatan Andalas 5(3): 661-665. https://doi.org/10.25077/jka.v5i3.595

Fausi, Mia. R. (2017). Pengaruh perhatian orang tua, disiplin belajar, dan motivasi belajar terhadap prestasi belajar akuntansi siswa kelas xi ips sma negeri 1 depok tahun ajaran 2016/2017. [Bachelor's thesis, Universitas Negeri Yogyakarta]. Retrieved July 18, 2019 from https://eprints. uny.ac.id/48915/1/SKRIPSI\%20FULL MIA\%20RIZKY\%20FAUSI_13803241030. pdf

Fawcett, J. (2017). Applying conceptual models of nursing: quality improvement, research, and practice. Springer Publishing Company.

Fisher, M. M., Rosen, D. S., Ornstein, R. M., Mammel, K. A., Katzman, D. K., Rome, E. S., Callahan, S. T., Malizio, J., Kearney, S., \& Walsh, B. T. (2014). Characteristics of avoidant/restrictive food intake disorder in children and adolescents: a "new disorder" in DSM-5. The Journal of adolescent health, 55(1), 49-52. https://doi.org/10.1016/j. jadohealth.2013.11.013 
Yoyok Bekti Prasetyo: Assosiations between Dependency Behavior and Management Ability

Groarke S. (2016). 'Though he slay me, yet will I trust in him': A critical reconstruction of Winnicott's theory of value. The International journal of psycho-analysis, 97(4), 1035-1056. https://doi.org/10.1111/1745-8315.12411

Haerunisa, D., Taftazani, B. M., \& Apsari, N. C. 2014. Pemenuhan kebutuhan dasar anak oleh panti sosial asuhan anak (PSAA). Prosiding Penelitian dan Pengabdian pada Masyarakat, 2(1): 25-30. https://doi. org/10.24198/jppm.v2i1.13232

Hansson, L. M., Heitmann, B. L., Larsson, C., Tynelius, P., Willmer, M., \& Rasmussen, F. (2016). Associations between swedish mothers' and 3- and 5-year-old children's food intake. Journal of Nutrition Education and Behavior 48(8): 520-529.e1. http:// dx.doi.org/10.1016/j.jneb.2016.05.015

Herschell, A.D., Scudder, A.B., Schaffner, K.F., Slagel, L.A. (2017) Feasibility and effectiveness of parent-child interaction therapy with victims of domestic violence: A pilot study. J Child Fam Stud 26, 271-283. https://doi.org/10.1007/s10826-016-0546-y

Hidayah, B. Nur. (2017). Pola asuh orang tua dalam mengembangkan kemandirian anak usia dini di Dukuh Branglor Mancasan Baki Sukoharjo. [Bachelor's thesis, Institut Agama Islam Negeri Surakarta]. IAIN Library. Retrieved August 11, 2019, from http://opac. iain-surakarta.ac.id/libsys iain surakarta/ opac/index.php/home/detäil_köleksi?kd_ buku $=029666$

Hidayati, N. (2011). Dukungan sosial bagi keluarga anak berkebutuhan khusus. (Social support for families of children with special Needs). Insan 13(01): 12-20.

Johnson, M., Maas, M., \& Moorhead, S. (2000). Nursing Outcomes Classification (NOC) second ed. Mosby-Year Book, Inc.

Kartiko, O. A. (2013). Pengaruh pendapatan orang tua terhadap peningkatan prestasi belajar siswa kelas $\mathrm{X}$ di SMKN 2 Jiwan Kabupaten Madiun. Equilibrium 1(2): 17479. http://doi.org/10.25273/equilibrium. v1i2.597
Kostro, K., Lerman, J. B., \& Attia, E. (2014). The current status of suicide and self-injury in eating disorders: A narrative review. Journal of Eating Disorders, 2(19). https:// doi.org/10.1186/s40337-014-0019-X

Labada, A., Ismanto, A. Y., \& Kundre, R. (2016). Hubungan karakteristik ibu dengan statusgizibalitayang berkunjungdiPuskesmas Bahu Manado. Journal Keperawatan, 4(1), 1-8. https://doi.org/10.35790/jkp.v4i1.11899

Lopez, N. V., Schembre, S., Belcher, B. R., O'Connor, S., Maher, J. P., Arbel, R., Margolin, G., \& Dunton, G. F. (2018). Parenting styles, food-related parenting practices, and children's healthy eating: A mediation analysis to examine relationships between parenting and child diet. Appetitel (128), 205-213. https://doi.org/10.1016/j. appet.2018.06.021

Bulechek, G. M., \& McCloskey, J. C. (1996). Nursing Interventions Classification (NIC) second edition. Mosby-Year Book, Inc.

Munthofiah, Siti. (2010). Hubungan antara pengetahuan, sikap, dan perilaku ibu dengan status gizi anak balita. [Master's thesis, Universitas Sebelas Maret]. Universitas Sebelas Maret. Retrieved August 8, 2019, from https://core.ac.uk/download/ pdf/12349302.pdf

Myrskylä, M., \& Fenelon,A. (2012). Maternal age and offspring adult health: evidence from the health and retirement study. Demography, 49(4), 1231-1257. https://doi.org/10.1007/ s13524-012-0132-x

Naim, R., Juniarti, N., \& Yamin, A. (2017). Pengaruh edukasi berbasis keluarga terhadap intensi ibu hamil untuk optimalisasi nutrisi pada 1000 hari pertama kehidupan. Jurnal Keperawatan Padjadjaran, 5(2). https://doi. org/10.24198/jkp.v5i2.475

Nicely, T. A., Lane-Loney, S., Masciulli, E., Hollenbeak, C. S., \& Ornstein, R. M. (2014). Prevalence and characteristics of avoidant/ restrictive food intake disorder in a cohort of young patients in day treatment for eating 
Yoyok Bekti Prasetyo: Assosiations between Dependency Behavior and Management Ability

disorders. Journal of Eating Disorders, 2(1), 21. https://doi.org/10.1186/s40337-0140021-3

Malik, A. I., Ratnawati, M., \& Prihantanti, N. G. (2017). Hubungan Pola Asuh Orang Tua dengan Perkembangan Anak Usia Toddler di Desa Sumbermulyo Kecamatan Jogoroto Kabupaten Jombang. Jurnal Bidan, 3(2), 4551.

Nurhayati. (2017). Pengaruh tingkat perhatian orang tua dan motivasi belajar terhadap prestasi belajar matematika siswa kelas III SD Muhammadiyah wirobrajan 3 Yogyakarta". [Bachelor's thesis, Universitas PGRI Yogyakarta]. Universitas PGRI Yogyakarta Repository. Retrieved July 19, from http://repository.upy.ac.id/155/

Rahayuwati, L., Nurhidayah, I., Hidayati, N. O., Hendrawati, S., Agustina, H. S., \& Ekawati, R. (2019). Analysis of factor affecting nutrition status on children. Jurnal Keperawatan Padjadjaran, 7(2), 119-133. https://doi.org/10.24198/jkp.v7i2.1131

Rarastiti, C. Nur., \& Syauqy, A. (2013). Hubungan karakteristik ibu, frekuensi kehadiran anak ke posyandu, asupan energi dan protein dengan status gizi anak usia 1-2 tahun. Journal of Nutrition College, 3(1), 98105. https://doi.org/10.14710/jnc.v3i1.4537

Rezky, Bunda. (2010). Be a Smart Parent. Jogja Bangkit Publisher.

Rohmah, E. N. (2017). Pengaruh Tingkat Pendapatan dan Perhatian Orang Tua Terhadap Hasil Belajar. [Bachelor's thesis, Universitas Negeri Semarang]. Universitas Negeri Semarang Library. Retrieved July 12, 2019, from http://lib.unnes. ac.id/31270/1/1401413128.pdf

Sitoresmi, F. (2014). Hubungan pola asuh orang tua dengan perilaku jajan anak sekolah dasar usia 10-12 tahun di SD Negeri Lebak Grabag Magelang. [Bachelor's thesis, Stikes 'Aisyiyah Yogyakarta]. Unisa Yogya Digilib. Retrieved July 12, 2019, from http://digilib. unisayogya.ac.id/322/1/NASKAH\%20
P U B L I K A S I \% 20 F I T R I A N A \% 20 SITORESMI\%20\%28090201058\%29.pdf

Solehati, T., Ermiati E., Trisyani, M., \& Hermayanti, Y. (2017). Hubungan sumber informasi dan usia remaja puteri dengan perilaku perawatan diri saat menstruasi. Jurnal Keperawatan Padjadjaran 5(2): 14554. http://dx.doi.org/10.24198/jkp.v5i2.452

Spruijt, A. M., Dekker, M. C., Ziermans, T. B., \& Swaab, H. (2018). Attentional control and executive functioning in schoolaged children: Linking self-regulation and parenting strategies. Journal of Experimental Child Psychology, 166, 340-359. https://doi. org/10.1016/j.jecp.2017.09.004

Taherdoost, H. (2018). Sampling methods in research methodology; how to choose a sampling technique for research. International Journal of Academic Research in Management, 5(2), 18-27. https://dx.doi. org/10.2139/ssrn.3205035

Taraban, L., \& Shaw, D. S. (2018). Parenting in context: Revisiting Belsky's classic process of parenting model in early childhood. Developmental Review, 48, 55-81. https:// doi.org/10.1016/j.dr.2018.03.006

Rahayu, S. Y., \& Rakhmawati, W. (2015). Strategi regulasi emosi kognitif dan pola asuh orangtua pada anak yang menjalani kemoterapi. Jurnal Keperawatan Padjadjaran, 1(3). https://doi.org/10.24198/ jkp.v1i3.68

Widyastuti, V. (2017). Hubungan tingkat pendapatan orang tua dan pola asuh Orang Tua terhadap prestasi belajar siswa. [Bachelor's thesis, Universitas Negeri Yogyakarta]. ePrints UNY. Retrieved July 12, 2019. from https://eprints.uny.ac.id/33654/

Zahra,A.(2018). HubunganAntara Dukungan Orangtua Dengan Adaptabilitas Karir Pada Siswa. [Bachelor's thesis, Universitas Negeri Sunan Ampel]. Universitas Negri Sunan Ampel. Retrieved July 14, 2019, from http:// digilib.uinsby.ac.id/26303/1/Afrilaili\%20 Zahra_J71214028.pdf 